\title{
PENGARUH VARIABEL MAKRO EKONOMI DAN PENYALURAN ZAKAT, INFAK, DAN SEDEKAH OLEH BADAN AMIL ZAKAT NASIONAL TERHADAP KEMISKINAN DI INDONESIA ${ }^{1}$
}

\author{
Jasmine Fitri Andrini \\ Departemen Ekonomi Syariah-Fakultas Ekonomi dan Bisnis-Universitas Airlangga \\ Email: jasmine.fitri.andrini-2015@feb.unair.ac.id \\ IImiawan Auwalin \\ Departemen Ekonomi Syariah-Fakultas Ekonomi dan Bisnis-Universitas Airlangga \\ Email: auwalin@feb.unair.ac.id
}

\begin{abstract}
:
This research aims to know the effect of macroeconomics variable, such as Gross Domestic Product (GDP), unemployment, inflation, and gini ratio and distribution of Zakat, Infaq, and Sodaqoh (ZIS) from National Zakat Agency against poverty in Indonesia during 2007 to 2017 simultaneously and partially in long run and short run. This study used vector error correction model technique. The result of this research indicates that GDP, inflation, gini ratio, and distribution of ZIS partially have a negative and significant effect to poverty in long run. Meanwhile, unemployment partially has a positive and significant effect to poverty in long run. In short run, GDP, inflation and distribution of ZIS partially have a negative and not significant effect to poverty, unemployment has a positive insignificant effect to poverty. Meanwhile, gini ratio partially has a significant and negative effect to poverty. Simultaneoosly, all variables affect poverty.
\end{abstract}

Keywords: Gross Domestic Product (GDP), Unemployment, Inflation, Gini ratio, Zakat Infaq Sodaqoh (ZIS), Poverty

\section{PENDAHULUAN}

\section{Latar Belakang}

Penyebab awal munculnya masalah-masalah pembangunan salah satunya adalah kemiskinan. Kemiskinan merupakan masalah yang begitu sering ditemui dan selalu terjadi dan dialami di berbagai belahan dunia, khususnya negara berkembang. Indonesia yang merupakan negara berkembang juga mengalami masalah tersebut. Karenanya, kemiskinan yang merupakan musuh paling utama untuk negeri ini harus dihilangkan. Pemerintah terus berupaya untuk mencegah dan menuntaskan kemiskinan yang masih terus berlangsung sampai saat ini. Hal ini ditunjukkan dengan tingkat kemiskinan di Indonesia dalam kurun waktu 10 tahun terakhir yang cenderung memiliki tren yang menurun dari waktu ke waktu. Namun menurut Jusmaliani (2005: 113), upaya-upaya yang dilakukan untuk mencegah dan menuntaskan kemiskinan tersebut, masih belum mendapatkan hasil yang optimal.

Baik buruknya suatu perekonomian suatu negara dapat dilihat menggunakan indikator tertentu yang bisa digunakan untuk menghasilkan pendapatan total dari seluruh masyarakat di dalamnya. Indikator tersebut yang juga penting untuk mengetahui perkembangan dan pertumbuhan ekonomi suatu negara di dalam suatu periode tertentu adalah

\footnotetext{
${ }^{1}$ Jurnal ini merupakan bagian dari skripsi Jasmine Fitri Andrini, NIM: 041511 433052, yang diuji pada tanggal 22 April 2019.
} 
Andrini, et al/Jurnal Ekonomi Syariah Teori dan Terapan Vol. 6 No. 7 Juli 2019: 1476-1493; PENGARUH VARIABEL MAKRO EKONOMI DAN PENYALURAN ZAKAT, INFAK, DAN SEDEKAH OLEH BADAN AMIL ZAKAT NASIONAL TERHADAP KEMISKINAN DI INDONESIA

Produk Domestik Bruto (PDB) atau dikenal dengan Gross Domestic Product (GDP) (BI, 2016). PDB Indonesia atas dasar harga konstan dengan tahun dasar 2010 pada 10 tahun terakhir ini terus mengalami kenaikan. Maka dari itu, diharapkan dengan naiknya PDB di Indonesia setiap tahunnya dapat menurunkan angka kemiskinan di Indonesia. Di samping itu, pemerintah harus terus melakukan suatu langkah-langkah tertentu untuk meningkatkan hasil PDB yang optimal.

Hal yang dapat menjadi salah satu penyebab terjadinya permasalahan kemiskinan adalah pengangguran. Hal ini disebabkan karena lapangan pekerjaan yang tersedia tidak bisa menampung banyaknya jumlah angkatan kerja yang ada, sehingga muncul banyak pengangguran. Pengangguran dapat diketahui melalui indikator Tingkat Pengangguran Terbuka (TPT). TPT menurut BPS (2018) ini merupakan suatu alat yang dapat mengetahui seberapa besar ukuran lapangan kerja yang tidak terpenuhi oleh angkatan kerja. TPT yang terjadi di Indonesia di 10 tahun belakangan ini mengalami fluktuasi, namun lebih didominasi oleh penurunan. Hal ini disebabkan karena lapangan kerja yang menjadi lebih luas (BPS, 2018).

Suatu hal yang menjadi masalah yang paling dihindari untuk terjadi di semua negara salah satunya adalah inflasi. Menurut Badan Pusat Statistik dalam laman resminya, inflasi ini diikuti dengan kenaikan dari harga-harga yang ada dan berlangsung dalam jangka waktu terus menerus. Inflasi pada tahun 2007 sampai dengan 2017 yang terjadi di Indonesia terus-menerus mengalami fluktuasi. Menurut Mankiw (2000: 165), inflasi yang terus mengalami fluktuasi akan berakibat pada terjadinya ketidakpastian dari kesejahteraan masyarakat dan daya beli masyarakat akan menurun.

Masalah yang dihadapi Indonesia selain kemiskinan, pengangguran, dan inflasi ialah ketimpangan ekonomi. Menurut BPS (2017: 19), ketimpangan distribusi pendapatan dapat menjadi pemicu kemiskinan. Maka, pembangunan untuk mencapai pertumbuhan harus menghasilkan pemerataan bagi masyarakat, bukan pertumbuhan yang lebih banyak dinikmati oleh kelompok masyarakat kaya dan dinikmati sedikit oleh kaum miskin (Hadliroh, 2014). Rasio gini Indonesia cenderung mengalami peningkatan, namun setelah tahun 2014, rasio gini menunjukkan tren yang menurun. Penurunan rasio gini ini menggambarkan bahwa ketimpangan distribusi pendapatan antara masyarakat di Indonesia ini semakin menunjukkan pemerataannya dibandingkan tahuntahun sebelumnya.

Islam memiliki instrumen kebijakan fiskal untuk menyelesaikan masalah kemiskinan, yaitu dengan zakat, infaq, dan sedekah. Zakat bagi muslim hukumnya adalah wajib dikerjakan, sedangkan hukum infaq maupun sedekah adalah sunnah atau sukarela. Indonesia 
Andrini, et al/Jurnal Ekonomi Syariah Teori dan Terapan Vol. 6 No. 7 Juli 2019: 1476-1493; PENGARUH VARIABEL MAKRO EKONOMI DAN PENYALURAN ZAKAT, INFAK, DAN SEDEKAH OLEH BADAN AMIL ZAKAT NASIONAL TERHADAP KEMISKINAN DI INDONESIA

merupakan negara yang diduduki oleh penduduk yang mayoritas memeluk agama Islam. Menurut data yang bersumber dari Badan Pusat Statistik, pada tahun 2010 sebanyak 87,18\% dari penduduk Indonesia menganut agama Islam. Oleh karena itu, dengan jumlah populasi penduduk muslim yang besar, maka potensi zakat di Indonesia juga besar. Besarnya potensi Zakat, Infaq, dan Sedekah (ZIS) ini menjadi peluang untuk melakukan pengentasan masyarakat miskin yang ada di Indonesia melalui pendistribusian ZIS.

Berangkat dari latar belakang tersebut penulis tertarik untuk mencari tahu bagaimana pengaruh Produk Domestik Bruto (PDB), pengangguran, inflasi, rasio gini, dan distribusi zakat, infaq, dan sedekah di Badan Amil Zakat Nasional (BAZNAS) terhadap kemiskinan di Indonesia.

\section{LANDASAN TEORI}

Bappenas (2016) dalam laman resminya menyatakan membaiknya perekonomian negara Indonesia dengan tingkat inflasi stabil dan relatif rendah, belanja pemerintah yang lebih efisien, pertumbuhan ekonomi membaik, dan tingkat pengangguran terbuka yang berkurang, tingkat kemiskinan menurun, dan investasi yang meningkat. Hal ini dapat disimpulkan bahwa hubungan antara pertumbuhan ekonomi yang diukur dengan Produk Domestik Bruto (PDB) terhadap kemiskinan berkorelasi negatif. Penelitian Akhmad, Alyas, dan Amir (2018) menyatakan pertumbuhan ekonomi (PDRB) memiliki hubungan negatif tetapi tidak langsung dampaknya terhadap pengurangan kemiskinan. Fauziyah (2016) menyatakan pertumbuhan ekonomi berpengaruh positif terhadap kemiskinan. Sementara itu, penelitian Mulok, Kogid, Asid, dan Lily (2012) menyatakan bahwa pertumbuhan ekonomi tidak dapat mengurangi kemiskinan dengan cepat dan juga tidak bisa memengaruhi kemiskinan dalam jangka waktu yang panjang.

Pengangguran bisa diartikan sebagai seseorang yang termasuk di dalam angkatan kerja namun tidak memiliki pekerjaan padahal sudah berusaha semaksimal mungkin untuk mendapatkan pekerjaan. Bekerja pada hakikatnya adalah untuk mendapatkan penghasilan demi mencukupi kebutuhan sehari-hari untuk individu maupun suatu kelompok rumah tangga. Apabila tidak bekerja, maka penghasilan atau pendapatan tidak didapatkan untuk memenuhi kebutuhan sehari-hari. Jika pendapatan tersebut sangat dibutuhkan untuk kebutuhan sehari-hari, maka pengangguran akan berdampak langsung terhadap kemiskinan.

Inflasi menurut Badan Pusat Statistik merupakan suatu kejadian dimana harga yang ada di pasar kecenderungan mengalami kenaikan yang pada umumnya terjadi dalam jangka waktu lama dan secara terus-menerus. Dengan terjadinya inflasi akan mengakibatkan 
Andrini, et al/Jurnal Ekonomi Syariah Teori dan Terapan Vol. 6 No. 7 Juli 2019: 1476-1493; PENGARUH VARIABEL MAKRO EKONOMI DAN PENYALURAN ZAKAT, INFAK, DAN SEDEKAH OLEH BADAN AMIL ZAKAT NASIONAL TERHADAP KEMISKINAN DI INDONESIA

masyarakat menjadi semakin miskin. Hal ini dikarenakan saat terjadi inflasi yang mana harga-harga barang dan jasa yang dibutuhkan untuk dikonsumsi oleh masyarakat secara terus-menerus menjadi mahal, sehingga masyarakat mengurangi jumlah konsumsinya. Penelitian dari Sugiartiningsih dan Shaleh (2007) menyatakan inflasi yang terjadi di Indonesia berpengaruh positif terhadap kemiskinan.

Menurut Todaro dalam (Putra, 2011), timpangnya distribusi pendapatan yang dapat dilihat dari rasio gini berpengaruh terhadap tingkat kemiskinan. Hal ini disebabkan karena terjadinya jumlah penduduk yang meningkat. Apabila jumlah penduduk meningkat, akan mengakibatkan angka kemiskinan semakin meningkat pula. Dengan adanya ketimpangan yang tinggi yang dilihat dari rasio gini, maka kemiskinan juga akan semakin banyak. Penelitian Akhmad, Alyas, dan Amir (2018) menyatakan adanya hubungan positif dan signifikan antara indeks gini dengan meningkatnya kemiskinan.

Menurut Hafidhuddin dalam Azis dkk. (2017: 2), zakat memiliki fungsi untuk menolong, membantu, dan membina fakir miskin kepada kehidupan yang lebih baik dan lebih sejahtera, sehingga kebutuhan hidupnya dapat dipenuhi oleh mereka, dapat beribadah kepada Allah SWT, kekufuran dapat dihindari, dan menjauhkan diri dari sifat iri dengki orang miskin ketika melihat orang kaya. Tujuan dari zakat utamanya adalah membantu kaum yang kurang beruntung secara ekonomi. Bantuan dana dari zakat, infak, dan sedekah tersebut memberi kesempatan bagi orang yang menerimanya untuk mengubah keadaan mereka menjadi lebih baik dengan tingkat sosial ekonomi yang lebih tinggi pula (Azis dkk., 2017: 3). Penelitian Fauziyah (2016) menyatakan dana ZIS di BAZNAS berpengaruh negatif dan signifikan terhadap kemiskinan di Indonesia. Seto (2016) menyatakan variabel ZIS memilliki pengaruh tidak signifikan terhadap kemiskinan

\section{METODE PENELITIAN}

Pendekatan yang digunakan dalam penelitian ini adalah pendekatan kuantitatif. Data yang digunakan dalam variabel PDB, pengangguran, inflasi, rasio gini, distribusi ZIS dari BAZNAS, dan kemiskinan berupa data time series.

PDB menurut Badan Pusat Statistik (BPS) merupakan total dari nilai tambah hasil dari seluruh unit usaha di suatu negara, yang merupakan jumlah dari nilai barang dan jasa akhir dari seluruh unit ekonomi. PDB yang dimaksud di dalam penelitian ini dihitung berdasarkan PDB atas dasar harga konstan di Indonesia. Jenis data adalah data bulanan, diambil sesuai dengan periode penelitian tahun 2007-2017 (dalam Rupiah). Data ini diambil dari data di laman BPS (Badan Pusat Statistik).

Pengangguran adalah orang yang sudah menginjak angkatan kerja dan 
Andrini, et al/Jurnal Ekonomi Syariah Teori dan Terapan Vol. 6 No. 7 Juli 2019: 1476-1493; PENGARUH VARIABEL MAKRO EKONOMI DAN PENYALURAN ZAKAT, INFAK, DAN SEDEKAH OLEH BADAN AMIL ZAKAT NASIONAL TERHADAP KEMISKINAN DI INDONESIA

sedang mencari pekerjaan namun belum didapatkannya. Data tingkat pengangguran terbuka yang ada di Indonesia dalam penelitian ini didapatkan dari Badan Pusat Statistik (BPS) dalam rentang waktu 2007-2017 (dalam satuan persen).

Inflasi adalah kejadian dimana harga barang dan jasa cenderung mengalami kenaikan yang berlangsung dalam jangka panjang. Data inflasi didapatkan dari laman resmi Badan Pusat Statistik (BPS) untuk tahun 2007-2017 (dalam satuan persen).

Rasio gini adalah salah satu indikator yang dapat dijadikan alat ukur untuk melihat suatu ketimpangan dan ketidakmerataan pendapatan. Rasio gini yang menggambarkan besarnya ketimpangan pendapatan tahun 2007 sampai dengan 2017 (dalam satuan indeks) didapatkan dari laman Badan Pusat Statistik (BPS).

Distribusi atau penyaluran dana zakat dilakukan untuk membantu kaum yang kurang beruntung secara ekonomi, khususnya yaitu untuk mengurangi tingkat kemiskinan. Data distribusi dana zakat didapatkan melalui data tahun 2007-2017 yang ada pada laman resmi BAZNAS dan melalui email dengan surat permohonan penelitian yang diajukan kepada BAZNAS, yang dinyatakan dalam Rupiah.

Kemiskinan adalah kondisi atau keadaan dimana masyarakat mengalami kesusahan untuk memenuhi kebutuhan pokok atau dasar hidupnya. Data tentang jumlah kemiskinan yang ada di Indonesia ini bersumber dari Badan Pusat Statistik dalam kurun waktu 2007-2017. Data jumlah kemiskinan dinyatakan dalam satuan jiwa.

Studi literatur menjadi langkah yang paling awal untuk mempelajari dan mengetahui teori dan acuan yang berasal dari buku, jurnal, penelitian, internet, dan lain sebagainya yang dapat menjelaskan masalah-masalah dalam penelitian ini. Kemudian, data-data sekunder dikumpulkan yang bersumber dari BPS dan BAZNAS yang telah tersaji dari internet atau laman resmi maupun sumber lain yang relevan untuk membuktikan teori sebelumnya.

Untuk melihat stasioneritas dari sebuah data dilakukan uji akar unit atau unit root test. Uji akar unit ini bisa menggunakan uji Augmented DickeyFuller (ADF) Test yang telah dibuat David Dickey dan Wayne Fuller. Apabila di dalam data tidak menunjukkan stasioneritas yang ada di orde nol atau I(0) atau tidak menunjukkan stasioneritas pada level, maka pada orde selanjutnya bisa dicari data yang stasioner yang bisa disebutkan bahwa tingkat stasioneritas di dalam data terjadi pada orde ke-n atau first difference, atau pada second difference. Menurut Enders (1995) dalam Rusdi (2011), persamaan uji tersebut dapat digunakan untuk menguji hipotesis nol $(\mathrm{HO})$. Cara pengujian hipotesis yaitu membandingkan ADF test hitung regresi dengan t statistic dari MacKinnon critical 
Andrini, et al/Jurnal Ekonomi Syariah Teori dan Terapan Vol. 6 No. 7 Juli 2019: 1476-1493; PENGARUH VARIABEL MAKRO EKONOMI DAN PENYALURAN ZAKAT, INFAK, DAN SEDEKAH OLEH BADAN AMIL ZAKAT NASIONAL TERHADAP KEMISKINAN DI INDONESIA

value (1\%, 5\%, 10\%). Jika ADF test hitung nilainya lebih kecil dibandingkan dengan Mackinnon critical value, maka HO ditolak dan $\mathrm{Hl}$ diterima dan di dalam persamaan model tersebut tidak mengandung unsur unit root atau bisa dikatakan data yang ada yaitu stasioner.

Uji kointegrasi berdasarkan Purnomo (2010), dilakukan karena adanya anggapan bahwa suatu model memiliki data yang tidak terkandung stasioner di dalamnya secara individu namun bisa terjadi stasioneritas apabila adanya kombinasi yang linear diantara lebih dari dua data dalam runtut waktu (time series). Melalui uji ini, menurut Inawati (2016), peneliti dapat melacak ada tidaknya hubungan yang terjadi di antara variabel yang terjadi pada jangka panjang. Uji kointegrasi dapat menggunakan metode Johansen \& Stock-Watson atau metode Engle Granger. Langkah untuk menguji kointegrasi pertama-tama ialah dengan mencari tahu terlebih dahulu lag optimal dan ada tidaknya tren dan intersep di dalam model. Apabila di dalam sebuah model nilai trace statistic dan max-eigen statistic lebih besar daripada critical value, maka di dalam penelitian tersebut menunjukkan bahwa sebuah model tersebut bersifat kointegrasi, begitu pula sebaliknya.

Teknik analisis dari penelitian ini menggunakan metode Vector Autoregression (VAR), Vector Error Correction Model (VECM), atau Autoregressive Distributed Lag (ARDL).
Asumsi untuk model VAR salah satunya adalah stasioner di tingkat level atau I(0) dan terkointegrasi. Sedangkan VECM memiliki data yang harus mengandung stasioneritas di diferensiasi pertama dan terkointegrasi (Basuki dan Prawoto, 2016: 22). Apabila suatu model stasioner dan tidak berkointegrasi, maka bisa menggunakan metode Autoregressive Distributed Lag (ARDL) (Rosadi, 2011 : 192).

\section{HASIL DAN PEMBAHASAN}

\section{Deskripsi Hasil Penelitian}

Penelitian ini menggunakan analisis data time series berbasis lag. Data bulanan yang digunakan dalam penelitian ini berasal dari statistik interpolasi dengan menggunakan software Eviews Quadratic Math-Sum, dikarenakan data yang dipublikasikan oleh Badan Pusat Statistik (BPS) adalah dalam bentuk tahunan untuk PDB, rasio gini, dan kemiskinan serta data dalam bentuk semesteran untuk pengangguran. Data yang berbentuk ribuan sampai dengan triliunan seperti PDB, distribusi ZIS di BAZNAS, dan kemiskinan dilakukan tabulasi data yang diubah ke dalam bentuk logaritma natural (Ln) agar di dalam interpretasi dapat menginterpretasikan sebagai persentase. Selain itu, dilakukan penyamaan tahun dasar untuk PDB, dikarenakan data PDB tahun 2007 menggunakan harga atas dasar tahun 2000, sedangkan sejak tahun 2011, PDB dihitung berdasarkan harga konstan tahun 2010. 
Andrini, et al/Jurnal Ekonomi Syariah Teori dan Terapan Vol. 6 No. 7 Juli 2019: 1476-1493; PENGARUH VARIABEL MAKRO EKONOMI DAN PENYALURAN ZAKAT, INFAK, DAN SEDEKAH OLEH BADAN AMIL ZAKAT NASIONAL TERHADAP KEMISKINAN DI INDONESIA

Untuk mengolah data, penelitian ini menggunakan aplikasi Eviews 9 untuk menguji stasioneritas dan kointegrasi pada data terlebih dahulu. Hasil yang didapatkan yaitu semua data yang ada bersifat stasioner pada tingkat ist difference dan terkointegrasi dengan lag optimal 2 melalui metode Johansen Cointegration. Maka, metode yang digunakan dalam penelitian ini yaitu Vector Error Correction Model (VECM) untuk mengetahui hubungan antar variabel dalam jangka panjang dan jangka pendek dan dilakukan Estimate Equation untuk mengetahui signifikansi pada jangka pendek. Kemudian dilakukan analisis Impulse Response Function (IRF) yang hasilnya dapat menggambarkan seberapa lama pengaruh antar variabel yang akan terjadi. Setelah itu, dilakukan analisis Variance Decomposition (VD) untuk mengetahui seberapa besar pengaruh antar variabel independen terhadap variabel dependen.

\section{Hasil Uji Akar Unit}

Untuk menguji data time series perlu dilakukan terlebih dahulu uji akar unit agar dapat diketahui bahwa data yang digunakan dalam penelitian ini bersifat stasioner atau tidak. Pengujian ini menggunakan melihat dengan menggunakan uji Augmented DickeyFuller (ADF).

Pengujian akar unit ini diberlakukan untuk masing-masing variabel, baik variabel independen yaitu
Produk Domestik Bruto (LNPDB), pengangguran (PENG), inflasi (INF), rasio gini (RGI), dan distribusi Zakat, Infak, dan Sedekah di Badan Amil Zakat (LNZIS) serta variabel dependen yaitu kemiskinan (MIS). Pengujian ini dimulai dari pengujian stasioneritas pada tingkat level, jika hasil pada tingkat level tidak menunjukkan stasioneritas, maka dilanjutkan dengan pengujian pada tingkat ${ }^{\text {st }}$ difference.

Hasil uji stasioneritas pada tingkat level dalam penelitian ini dapat dilihat dari Tabel 1. Dari tabel tersebut dapat diketahui bahwa tidak ada satupun variabel yang stasioner atau memiliki akar unit pada tingkat level. Hal ini dikarenakan pada masing-masing variabel menunjukkan bahwa ADF test hitung lebih kecil daripada MacKinnon Critical Value. Begitu pula pada Probabilitas masingmasing variabel tidak menunjukkan signifikan karena lebih besar daripada a yang dipakai yaitu 0,05. Sedangkan pada Tabel 2, semua variabel sudah stasioner pada tingkat ${ }^{\text {st }}$ difference.

Tabel 1.

Hasil Uji Stasioneritas ADF di Tingkat Level

\begin{tabular}{|c|c|c|c|c|c|}
\hline \multirow{2}{*}{ Variabel } & \multirow{2}{*}{$\begin{array}{c}\text { ADF } \\
\text { Statistik }\end{array}$} & \multirow{2}{*}{ Prob. } & \multicolumn{3}{|c|}{ MacKinnon Critical Value } \\
\hline & & & $1 \%$ & $5 \%$ & $10 \%$ \\
\hline LNPDB & $\begin{array}{c}- \\
0.946089\end{array}$ & 0.9466 & $\begin{array}{c}- \\
4.030729\end{array}$ & $\begin{array}{c}- \\
3.445030\end{array}$ & $\begin{array}{c}- \\
3.147382\end{array}$ \\
\hline PENG & $\begin{array}{c}- \\
2.836406\end{array}$ & 0.1872 & $\begin{array}{c}- \\
4.030729\end{array}$ & $\begin{array}{c}- \\
3.445030\end{array}$ & $\begin{array}{c}- \\
3.147382\end{array}$ \\
\hline INF & $\begin{array}{c}- \\
2.808452\end{array}$ & 0.1971 & $\begin{array}{c}- \\
4.031309\end{array}$ & $\begin{array}{c}- \\
3.445308\end{array}$ & $\begin{array}{c}- \\
3.147545\end{array}$ \\
\hline RGI & 0.414726 & 0.9990 & $\begin{array}{c}- \\
4.036983\end{array}$ & $\begin{array}{c}- \\
3.448021\end{array}$ & $\begin{array}{c}- \\
3.149135\end{array}$ \\
\hline LNZIS & $\begin{array}{c}- \\
3.007576\end{array}$ & 0.1343 & $\begin{array}{c}- \\
4.031309\end{array}$ & $\begin{array}{c}- \\
3.445308\end{array}$ & $\begin{array}{c}- \\
3.147545\end{array}$ \\
\hline MIS & $\begin{array}{c}- \\
1.768268\end{array}$ & 0.7145 & $\begin{array}{c}- \\
4.030729\end{array}$ & $\begin{array}{c}- \\
3.445030\end{array}$ & $\begin{array}{c}- \\
3.147382\end{array}$ \\
\hline
\end{tabular}


Andrini, et al/Jurnal Ekonomi Syariah Teori dan Terapan Vol. 6 No. 7 Juli 2019: 1476-1493; PENGARUH VARIABEL MAKRO EKONOMI DAN PENYALURAN ZAKAT, INFAK, DAN SEDEKAH OLEH BADAN AMIL ZAKAT NASIONAL TERHADAP KEMISKINAN DI INDONESIA

Sumber: Hasil Estimasi Menggunakan EViews

Tabel 2.

Hasil Uji Stasioneritas ADF di Tingkat First Difference

\begin{tabular}{|c|c|c|c|c|c|}
\hline \multirow{2}{*}{$\begin{array}{c}\text { Variabe } \\
1\end{array}$} & \multirow{2}{*}{ ADF } & \multirow{2}{*}{ Statistik } & Prob. & \multicolumn{3}{|c|}{ MacKinnon Critical Value } \\
\cline { 4 - 6 } LNPDB & & & $1 \%$ & $5 \%$ & $10 \%$ \\
\hline \multirow{2}{*}{ PENG } & $-128089^{*}$ & 0.002 & 4.03072 & 3.44503 & 3.14738 \\
& & 0 & 9 & 0 & 2 \\
\hline \multirow{2}{*}{ INF } & $-5.605582^{*}$ & 0.000 & 4.03698 & 3.44802 & - \\
& & 0 & 3 & 1 & 5 \\
\hline \multirow{2}{*}{ RGI } & - & & - & - & - \\
& $3.929663^{*}$ & 0.013 & 4.03072 & 3.44503 & 3.14738 \\
& $*$ & 5 & 9 & 0 & 2 \\
\hline \multirow{2}{*}{ LNZIS } & $3.565803^{*}$ & 0.036 & 4.03072 & 3.44503 & 3.14738 \\
& $*$ & 8 & 9 & 0 & 2 \\
\hline \multirow{2}{*}{ MIS } & & 0.012 & 4.03766 & 3.44834 & 3.14932 \\
& $-4.465068^{*}$ & 5 & 9 & 0 & 2 \\
\hline
\end{tabular}

Sumber: Hasil Estimasi Menggunakan

EViews

* signifikan pada $a=1 \%$;

** signifikan pada $a=5 \%$

\section{Penentuan Lag Optimal}

Sebelum melakukan uji kointegrasi, perlu dilakukan penentuan lag optimal agar dapat diperoleh lag atau selang waktu yang tepat. Hal ini dikarenakan apabila lag yang diaplikasikan terlalu sedikit, maka residual tidak akan menampilkan white noise, yang akan menyebabkan standar kesalahan tidak diestimasi secara baik. Sebaliknya, apabila lag terlalu banyak akan mengurangi kemampuan untuk menerima $\mathrm{Hl}$ dan menolak HO karena dapat mengurangi degrees of freedom (Harris, 1995: 65).

Hasil uji Lag Optimal terdapat lima kriteria, yaitu Likelihood Ratio (LR), Final Prediction Error (FPE), Akaike Information Criterion (AIC), Schwarz Information Criterion (SC), dan Hannad-Quin Criterion (HQ). Dari hasil uji lag optimal yang dapat dilihat melalui Tabel 3 menunjukkan bahwa ada beberapa kriteria yang memberikan referensi lag optimal yang sama dan juga ada beberapa kriteria yang memberikan refensi lag optimal yang berbeda. Kriteria LR, FPE, dan AIC merekomendasikan lag 2 sebagai lag optimal. Sedangkan kriteria SC dan HQ merekomendasikan lag 1 sebagai lag optimal. Dengan perbedaan dari hasil uji lag optimal dari masing-masing kriteria, maka dipilih lag yang memiliki paling banyak rekomendasi dari 5 kriteria yang ada atau dengan melihat jumlah bintang terbanyak, yakni lag 2.

\section{Tabel 3.}

\section{Hasil Uji Lag Optimal}

\begin{tabular}{|c|c|c|c|c|c|c|}
\hline Lag & LogL & LR & FPE & AIC & SC & HQ \\
\hline 0 & 1480.162 & NA & $1.90 \mathrm{e}-18$ & -23.77681 & -23.64035 & -23.72138 \\
\hline 1 & 3648.969 & 4092.747 & $2.19 \mathrm{e}-33$ & -58.17691 & $-57.22166^{*}$ & $-57.78887 *$ \\
\hline 2 & 3703.356 & $97.37130 *$ & $1.63 \mathrm{e}-33 *$ & $-58.47349 *$ & -56.69944 & -57.75283 \\
\hline \multicolumn{7}{|c|}{ * indicates lag order selected by the criterion } \\
\hline
\end{tabular}

Sumber: Hasil Estimasi Menggunakan

EViews

\section{Hasil Uji Kointegrasi}

Sebelum melakukan uji kointegrasi, perlu dilakukan pengujian untuk mengetahui ada tidaknya tren dan intersep di dalam model yang ada dalam penelitian ini. Pengujian tersebut 
Andrini, et al/Jurnal Ekonomi Syariah Teori dan Terapan Vol. 6 No. 7 Juli 2019: 1476-1493; PENGARUH VARIABEL MAKRO EKONOMI DAN PENYALURAN ZAKAT, INFAK, DAN SEDEKAH OLEH BADAN AMIL ZAKAT NASIONAL TERHADAP KEMISKINAN DI INDONESIA

menggunakan Johansen Cointegration Test Summary. Hasil dari pengujian tersebut dapat dilihat dari Tabel 4 yang menyatakan bahwa model dari penelitian ini memiliki intersep dan tidak memiliki tren. Hal ini dikarenakan hasil dari Trace dan Max-Eig yang terbesar berada pada kolom Intercept dan No Trend.

\section{Tabel 4.}

Hasil Johansen Cointegration Test

\section{Summary}

\begin{tabular}{|c|c|c|c|c|c|}
\hline $\begin{array}{c}\text { Data } \\
\text { Trend: }\end{array}$ & None & None & Linear & Linear & Quadratic \\
\hline Test Type & $\begin{array}{c}\text { No } \\
\text { Intercept }\end{array}$ & Intercept & Intercept & Intercept & Intercept \\
\hline & No Trend & No Trend & No Trend & Trend & Trend \\
\hline Trace & 3 & 5 & 3 & 4 & 2 \\
\hline Max-Eig & 2 & 3 & 1 & 0 & 0 \\
\hline
\end{tabular}

Sumber: Hasil Estimasi Menggunakan

EViews

Pengujian kointegrasi dalam penelitian ini menggunakan Johansen Cointegration. Dalam metode Johansen Cointegration terdapat 2 penelitian statistik yaitu Trace Test dan Max-Eigen Test. Apabila hasil statistik dari keduanya menunjukkan hasil yang lebih besar dari nilai kritisnya yaitu 0,05, maka model dianalisis terkointegrasi.

\section{Tabel 5.}

\section{Hasil Johansen Cointegration Test (Trace}

\section{Statistic)}

\begin{tabular}{|c|c|c|c|c|}
\hline $\begin{array}{c}\text { Hypothesize } \\
\mathrm{d} \\
\text { No. of CE(s) }\end{array}$ & Eigenvalue & $\begin{array}{c}\text { Trace } \\
\text { Statistic }\end{array}$ & $\begin{array}{c}0.05 \\
\text { Critical } \\
\text { Value }\end{array}$ & Prob.** \\
\hline None $*$ & 0.269132 & 125.9610 & 95.75366 & 0.0001 \\
\hline At most $1 *$ & 0.227176 & 85.51656 & 69.81889 & 0.0017 \\
\hline At most 2* & 0.202294 & 52.27269 & 47.85613 & 0.0182 \\
\hline
\end{tabular}

\begin{tabular}{|l|l|l|l|l|}
\hline At most 3 & 0.093903 & 23.11672 & 29.79707 & 0.2404 \\
\hline At most 4 & 0.077398 & 10.39613 & 15.49471 & 0.2515 \\
\hline At most 5 & $3.28 \mathrm{E}-05$ & 0.004229 & 3.841466 & 0.9468 \\
\hline
\end{tabular}

Trace test indicates 3 cointegrating eqn(s) at the 0.05 level

* denotes rejection of the hypothesis at the 0.05 level **MacKinnon-Haug-Michelis (1999) p-alues

Sumber: Hasil Estimasi Menggunakan EViews

Hasil dari Johansen Cointegration Test untuk Trace Statistic yang dapat dilihat pada Tabel 5 menunjukkan bahwa terdapat 3 hasil Trace Statistic yang melebihi nilai kritisnya pada nilai kritis $5 \%$. Hal ini berarti terdapat minimal 3 rank yang terkointegrasi pada tingkat signifikan $5 \%$ atau tingkat keyakinan $95 \%$ yang artinya ada minimal 3 persamaan kointegrasi yang dapat menjelaskan dari masing-masing model yang ada. Maka dapat disimpulkan bahwa adanya kointegrasi dan keseimbangan di dalam jangka panjang antar variabel.

\section{Hasil Estimasi VECM}

Hasil estimasi dari Vector Correction Model (VECM) dalam Tabel 6. Persamaan dari hasil estimasi VECM di dalam jangka panjang sebagai berikut: MISKIN $_{\dagger}=22,45603-0,424230$ LNPDB $_{t-1}+$

$$
(4,14670)
$$

$$
\begin{aligned}
& \text { 0,279996 PENG }{ }_{t-1}-0,185362 \mathrm{NFF}_{\mathrm{t}-1} \text { - } \\
& (-2,29215) \quad(7,08450) \\
& 21,\left.04931 R^{R G}\right|_{t-1}-0,66179 \text { LNZIS } S_{-} \\
& \text {1........ (1) } \\
& (9,96479)
\end{aligned}
$$

angka dalam kurung adalah nilai t-statistik 
Andrini, et al/Jurnal Ekonomi Syariah Teori dan Terapan Vol. 6 No. 7 Juli 2019: 1476-1493; PENGARUH VARIABEL MAKRO EKONOMI DAN PENYALURAN ZAKAT, INFAK, DAN SEDEKAH OLEH BADAN AMIL ZAKAT NASIONAL TERHADAP KEMISKINAN DI INDONESIA

Melalui persamaan di atas dapat diketahui bahwa di dalam jangka panjang variabel Produk Domestik Bruto (PDB) memiliki hubungan yang negatif terhadap kemiskinan di Indonesia. Hasil dari persamaan estimasi VECM dalam jangka panjang menunjukkan bahwa PDB secara signifikan memiliki pengaruh terhadap kemiskinan karena nilai t-statistik dari PDB yaitu $[4,14670]$ lebih besar dibandingkan 1,96 yaitu nilai t-tabel untuk tingkat signifikansi $5 \%$. Hal ini membuktikan bahwa $H_{1}$ diterima yang menyatakan adanya hubungan signifikan. Jadi, PDB dalam jangka panjang memiliki pengaruh signifikan dengan arah negatif terhadap kemiskinan di Indonesia yang berarti bahwa setiap kenaikan satu persen pada PDB maka kemiskinan akan turun sebesar $0,42 \%$, ceteris paribus.

Variabel pengangguran memiliki hubungan yang positif terhadap kemiskinan. Hasil estimasi untuk jangka panjang menunjukkan adanya hubungan yang positif antar variabel pengangguran dan kemiskinan adalah signifikan. Hal ini dikarenakan t-statistik yaitu sebesar [2,29215] lebih besar dari 1,96 yang berarti $\mathrm{H}_{0}$ ditolak. Artinya pengangguran secara signifikan berpengaruh secara positif terhadap kemiskinan yang mana apabila pengangguran mengalami kenaikan sebesar satu persen, maka kemiskinan akan naik sebesar 0,28 persen, ceteris paribus.

Untuk variabel inflasi, terdapat hubungan yang negatif terhadap kemiskinan dan signifikan antara variabel inflasi dan kemiskinan, karena t-statistik sebesar [7,08450] yang lebih besar dari 1,96, yang berarti $\mathrm{H}_{0}$ ditolak. Hal tersebut dapat diartikan bahwa inflasi berpengaruh negatif dan signifikan terhadap kemiskinan, yang berarti apabila inflasi mengalami kenaikan sebesar satu persen, maka kemiskinan mengalami penurunan sebesar 0,19 persen, ceteris paribus.

Rasio gini yang dapat dilihat dari persamaan 4.1, menunjukkan hubungan yang negatif, karena di dalam Persamaan tersebut variabel rasio gini memiliki nilai yang bertanda negatif. Hasil estimasi jangka panjang VECM didapatkan bahwa adanya hubungan negatif dan signifikan antara rasio gini dan kemiskinan karena nilai t-statistik $[9,96479]$ lebih besar dari 1,96 yang berarti menerima $H_{1}$. Artinya, apabila rasio gini mengalami peningkatan sebesar 1 poin, maka kemiskinan mengalami penurunan sebesar 21,05 persen, ceteris paribus.

Variabel distribusi Zakat, Infak, dan Sedekah dari Badan Amil Zakat Nasional terhadap kemiskinan berdasarkan persamaan 4.1 memiliki hubungan yang negatif karena konstantanya ialah negatif. Untuk hasil estimasi di dalam jangka panjang menghasilkan bahwa terdapat hubungan yang negatif dan signifikan antara distribusi ZIS di BAZNAS terhadap kemiskinan. Hal ini dikarenakan t-statistik sebesar [3,27128] lebih besar dari 1,96. Ini berarti setiap kenaikan 1 persen dari 
Andrini, et al/Jurnal Ekonomi Syariah Teori dan Terapan Vol. 6 No. 7 Juli 2019: 1476-1493; PENGARUH VARIABEL MAKRO EKONOMI DAN PENYALURAN ZAKAT, INFAK, DAN SEDEKAH OLEH BADAN AMIL ZAKAT NASIONAL TERHADAP KEMISKINAN DI INDONESIA

distribusi ZIS dari BAZNAS, maka kemiskinan akan berkurang sebesar 0,07 persen, ceteris paribus.

$$
\begin{gathered}
\Delta \text { MISKIN }_{+}=0,362372-0,081030 \Delta \mathrm{LNPDB}_{+}+ \\
(0,0859) \\
0,00875 \Delta \mathrm{PENG}_{+}-0,185362 \Delta \mathrm{INF}_{\dagger}- \\
(0,4380) \\
21,04931 \Delta \mathrm{RG}_{+}- \\
0,66179 \Delta \mathrm{LNZIS}_{+} \ldots \ldots . . .(2) \\
(0,0156) \quad(0,8311)
\end{gathered}
$$

angka dalam kurung adalah nilai p-value

Di dalam estimasi di dalam jangka pendek di atas, PDB tidak menunjukkan memiliki hubungan yang signifikan secara statistik terhadap kemiskinan karena $\mathrm{p}$ value di Tabel 7 sebesar 0,0859 lebih besar dibandingkan tingkat signifikannnya yaitu 0,05 . Melalui persamaan 4.2 di atas, jangka pendek PDB memiliki konstanta negatif dan tidak signifikan secara statistik. Artinya, setiap kenaikan satu persen PDB di bulan sebelumnya, maka kemiskinan akan turun sebesar 1,02 persen, ceteris paribus.

Variabel pengangguran di dalam jangka pendek memiliki hubungan yang tidak signifikan secara statistik dan positif terhadap kemiskinan karena nilai $p$-value di dalam Tabel 7 yaitu sebesar 0,4380 yang melebihi tingkat signifikan yang digunakan yaitu 0,05 dan dilihat melalui persamaan 4.2 bahwa pengangguran memiliki konstanta yang positif. Jadi, apabila terjadi kenaikan satu persen pengangguran di bulan sebelumnya, maka kemiskinan akan naik sebesar 0,03 persen, ceteris paribus.
Inflasi dalam estimasi jangka pendek memiliki hubungan yang tidak signifikan secara statistik dan negatif terhadap kemiskinan. Hal ini dibuktikan dengan nilai $p$-value di dalam Tabel 7 yang sebesar 0,2636 yang nilainya lebih kecil dari tingkat signifikan yang digunakan yaitu 0,05 dan memiliki konstanta yang negatif yang dapat dilihat melalui persamaan 4.2. \$Bd 28\%apat diartikan bahwa apabila inflasi mengalami kenaikan di bulan sebelumnya, maka kemiskinan akan mengalami penurunan 0,02 persen, ceteris paribus.

Pengaruh antara rasio gini terhadap kemiskinan adalah negatif dalam jangka pendek. Hal ini dapat dibuktikan melalui persamaan 4.2 yang menunjukkan persamaan di dalam jangka pendek yang mana rasio gini di dalam Persamaan tersebut memiliki konstanta yang negatif. Untuk jangka pendek, rasio gini memiliki hubungan yang signifikan secara statistik. Hal ini dikarenakan nilai $p$ value di dalam Tabel 7 yaitu sebesar 0,0156 yang lebih kecil dari tingkat signifikan yang digunakan yaitu 0,05. Jadi, apabila terjadi kenaikan rasio gini sebesar satu poin di bulan sebelumnya, maka akan mengakibatkan penurunan jumlah kemiskinan sebesar 4,5 persen, ceteris paribus.

Hasil yang dihasilkan di dalam jangka pendek untuk variabel ZIS terhadap kemiskinan menunjukkan hubungan yang negatif dan tidak 
Andrini, et al/Jurnal Ekonomi Syariah Teori dan Terapan Vol. 6 No. 7 Juli 2019: 1476-1493; PENGARUH VARIABEL MAKRO EKONOMI DAN PENYALURAN ZAKAT, INFAK, DAN SEDEKAH OLEH BADAN AMIL ZAKAT NASIONAL TERHADAP KEMISKINAN DI INDONESIA

signifikan secara statistik. Hal ini dikarenakan hasil yang diperoleh di dalam jangka pendek menghasilkan $p$ value di dalam Tabel 7 yang sebesar 0,8311 yang lebih besar dari tingkat signifikan yang digunakan yaitu 0,05. Maka, apabila terjadi kenaikan dari jumlah distribusi ZIS dari BAZNAS sebesar satu persen, maka akan mengurangi angka kemiskinan sebesar 0,002 persen, ceteris paribus.

Nilai dari koreksi kesalahan dalam jangka pendek ke jangka panjang ialah sebesar -0,037142. Deviasi dari tahun sebelumnya untuk keseimbangan jangka panjang dapat dikoreksi pada tingkat kecepatan sebesar $3,7 \%$. Hasil tersebut diperoleh dari error correction di dalam jangka pendek bernilai -0,037142 yang memiliki keofisien negatif. Ini berarti bahwa model yang ada sudah valid. Maka dapat disimpulkan bahwa adanya kausalitas antara variabel independen terhadap variabel dependen di dalam jangka panjang.

Hasil yang diperoleh untuk F-statistik ialah 26.74119 . Nilai ini adalah lebih besar jika dibandingkan dengan F-tabelnya yaitu 2,286184 di tingkat signifikansi sebesar 5\%. Hal ini menunjukkan bahwa dalam jangka panjang semua variabel signifikan adanya untuk digunakan sebagai model pengestimasian.

Tabel 6.

Hasil Estimasi Vector Correction Model (VECM)

\begin{tabular}{|c|c|c|c|c|}
\hline & Hasil Estimasi Pers & Jangka Panjang & Hasil Estimasi Per & n Jangka Pendek \\
\hline Variabel Dependen & Cointegrating Eq & CointEq1 & Error Correction & D (MISKIN) \\
\hline \multirow{19}{*}{ MIS } & MIS & 1.0000 & \multirow{3}{*}{ CointEq1 } & -0.027142 \\
\hline & \multirow[t]{3}{*}{ PDB } & 0.424230 & & $(0.00845)$ \\
\hline & & $(0.10231)$ & & {$[-3.21041]$} \\
\hline & & {$[4.14670]$} & \multirow{3}{*}{ D(MIS (-1)) } & 0.295133 \\
\hline & \multirow[t]{3}{*}{ PENG } & -0.279996 & & $(0.17726)$ \\
\hline & & $(0.12215)$ & & [ 1.66493] \\
\hline & & {$[-2.29215]$} & \multirow{3}{*}{$\mathrm{D}(\mathrm{PDB}(-1))$} & 1.015622 \\
\hline & \multirow[t]{3}{*}{ INF } & 0.185362 & & $(0.59063)$ \\
\hline & & $(0.02616)$ & & [ 1.71956$]$ \\
\hline & & [ 7.08450] & \multirow{3}{*}{ D(PENG(-1)) } & -0.033220 \\
\hline & \multirow[t]{3}{*}{ RGI } & 21.04931 & & $(0.04281)$ \\
\hline & & $(2.11237)$ & & {$[-0.77594]$} \\
\hline & & [ 9.96479] & \multirow{3}{*}{$\mathrm{D}(\operatorname{INF}(-1))$} & -0.015755 \\
\hline & \multirow[t]{3}{*}{ ZIS } & 0.066179 & & $(0.01408)$ \\
\hline & & $(0.02023)$ & & {$[-1.11882]$} \\
\hline & & [3.27128] & \multirow{3}{*}{ D(RGI(-1)) } & 104863 \\
\hline & $\mathrm{C}$ & $-22,45603$ & & $(1.85799)$ \\
\hline & R-Squared & 0.605419 & & [ 2.42459] \\
\hline & F-statistic & 26.74119 & $\mathrm{D}(\mathrm{ZIS}(-1))$ & -0.001923 \\
\hline
\end{tabular}




$$
\begin{aligned}
& \text { ( ) = Standar error } \\
& {[]=\text { t-statistic }}
\end{aligned}
$$

Sumber: Hasil Estimasi Menggunakan EViews

\begin{tabular}{|c|c|}
\hline \multirow{2}{*}{} & $(0.01970)$ \\
\cline { 2 - 2 } & {$[0.03571]$} \\
\hline \multirow{3}{*}{$C$} & -0.006288 \\
\cline { 2 - 2 } & $(0.00289)$ \\
\cline { 2 - 2 } & {$[-2.17318]$} \\
\hline
\end{tabular}

Tabel 7.

\section{Hasil Estimasi Persamaan}

\begin{tabular}{|c|c|c|c|c|}
\hline Variabel & Koefisien & Standard Error & t-Statistic & Prob. \\
\hline PDB & 1.015622 & 0.590628 & 1.719563 & 0.0859 \\
\hline PENG & -0.033220 & 0.042812 & -0.775942 & 0.4380 \\
\hline INF & -0.015755 & 0.014081 & -1.118824 & 0.2636 \\
\hline RGI & 104863 & 1.857990 & 2.424590 & 0.0156 \\
\hline ZIS & -0.001923 & 0.009012 & -0.213368 & 0.8311 \\
\hline
\end{tabular}

Sumber: Hasil Estimasi Menggunakan EViews

Impulse Response Function (IRF)

Untuk melihat suatu akibat yang ditimbulkan oleh guncangan atau shock dari suatu variabel terhadap variabel lain tidak hanya di dalam jangka pendek tetapi juga di dalam jangka panjang ialah dengan cara menganalisis Impulse Response Function (IRF). Dengan analisis IRF, dapat diketahui suatu dampak dalam rentang waktu jangka panjang yang ada di dalam variabel bila terdapat suatu guncangan yang bernilai satu standard error yang ada di persamaan. Melalui analisis ini juga dapat diketahui seberapa lama periode terjadinya dampak dari variabel tertentu.

Gambar 1 menunjukkan response variabel kemiskinan terhadap guncangan dari variabel PDB, pengangguran, inflasi, rasio gini, dan ZIS di BAZNAS. Sumbu horizontal pada grafik menggambarkan ukuran waktu di dalam periode bulan untuk mendatang setelah adanya guncangan. Sedangkan untuk sumbu vertikal menjelaskan nilai respon yang diterima.

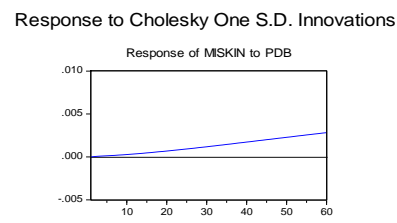

Response to Cholesky One S.D. Innovations

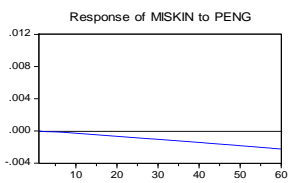

Response to Cholesky One S.D. Innovations

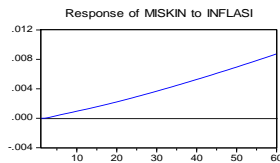

Response to Cholesky One S.D. Innovations

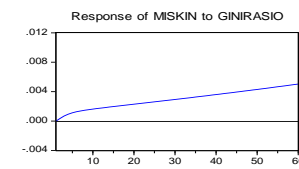

Response to Cholesky One S.D. Innovations

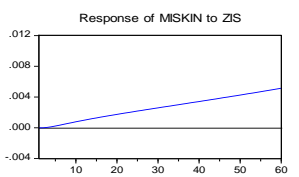

Sumber: Hasil Estimasi Menggunakan

EViews 
Andrini, et al/Jurnal Ekonomi Syariah Teori dan Terapan Vol. 6 No. 7 Juli 2019: 1476-1493; PENGARUH VARIABEL MAKRO EKONOMI DAN PENYALURAN ZAKAT, INFAK, DAN SEDEKAH OLEH BADAN AMIL ZAKAT NASIONAL TERHADAP KEMISKINAN DI INDONESIA

\section{Gambar 1.}

\section{Hasil Impulse Response Function}

Response yang diberikan variabel miskin saat terjadi guncangan negatif pada PDB yang ditunjukkan pada Gambar 1 kolom pertama baris ialah positif sejak awal periode yang mencapai titik tertinggi pada periode ke-60 yang sebesar 0,47\%. Hal ini menunjukkan jika adanya guncangan negatif sebesar 1 standard error pada PDB akan menambah jumlah kemiskinan di dalam jangka panjang dan jangka pendek.

Response dari variabel miskin saat terjadi guncangan negatif pada pengangguran menunjukkan response yang negatif mulai dari periode awal hingga periode ke-60 dapat dilihat pada Gambar 1 kolom pertama baris kedua. Hal ini menunjukkan jika adanya guncangan negatif sebesar 1 standard error pada pengangguran akan mengurangi jumlah kemiskinan di dalam jangka panjang dan jangka pendek.

Dari Gambar 1 pada kolom kedua baris pertama menunjukkan response variabel miskin saat terjadi guncangan negatif pada inflasi yang positif sejak awal periode dan terus meningkat hingga mencapai titik tertinggi sebesar $0,87 \%$ pada periode terakhir. Hal ini menunjukkan jika adanya guncangan negatif sebesar 1 standard error pada inflasi maka akan menambah jumlah kemiskinan di dalam jangka panjang dan jangka pendek.
Response dari variabel miskin saat terjadi guncangan negatif pada rasio gini yang dapat dilihat dalam Gambar 1 kolom kedua baris kedua, merespon secara positif dari periode awal sampai dengan periode akhir dengan titik tertinggi sebesar $0,50 \%$. Hal ini menunjukkan jika adanya guncangan negatif sebesar 1 standard error pada rasio gini maka akan menaikkan jumlah kemiskinan di dalam jangka panjang dan jangka pendek.

Response untuk variabel miskin saat terjadi guncangan negatif pada distribusi ZIS di BAZNAS yang dapat dilihat melalui Gambar 1 kolom ketiga ialah positif sejak awal periode dan terus meningkat hingga mencapai titik tertinggi yang terletak di periode terakhir sebesar $0,51 \%$. Hal ini menunjukkan jika adanya guncangan negatif sebesar 1 standard error pada ZIS maka akan menambah kemiskinan di dalam jangka panjang dan jangka pendek.

\section{Variance Decomposition}

Analisis ini menghasilkan informasi tentang proporsi dari pergerakan guncangan yang ada di dalam suatu variabel terhadap guncangan di dalam variabel lainnya untuk saat ini dan untuk saat yang mendatang. Pengujian ini juga digunakan untuk membuat forecast error variance untuk mengukur seberapa kuatnya variabel-variabel yang dapat memengaruhi variabel lainnya di saat ini dan di saat nanti (Beik dan Aprianti, 2013). 
Andrini, et al/Jurnal Ekonomi Syariah Teori dan Terapan Vol. 6 No. 7 Juli 2019: 1476-1493; PENGARUH VARIABEL MAKRO EKONOMI DAN PENYALURAN ZAKAT, INFAK, DAN SEDEKAH OLEH BADAN AMIL ZAKAT NASIONAL TERHADAP KEMISKINAN DI INDONESIA

Berdasarkan Tabel 8, pada periode pertama, kemiskinan hanya dipengaruhi oleh variabel kemiskinan sendiri Di periode kedua, variabel kemiskinan tidak hanya dipengaruhi oleh variabel kemiskinan saja, namun dipengaruhi oleh variabel lain seperti PDB sebesar $0,07 \%$, pengangguran sebesar $0,05 \%$, inflasi sebesar $0,0006 \%$, rasio gini sebesar 1,5\%, dan ZIS sebesar 0,0002\%. Kontribusi pengaruh dari variabel-variabel yang ada yaitu PDB, pengangguran, inflasi, rasio gini, dan distribusi ZIS di BAZNAS terus meningkat dari periode kedua hingga periode kesepuluh. Variabel yang memberikan kontribusi paling besar kepada kemiskinan ialah rasio gini, diikuti inflasi, PDB, ZIS, dan pengangguran.

Tabel 8.

Hasil Variance Decomposition dari Kemiskinan

\begin{tabular}{|c|c|c|c|c|c|c|c|}
\hline$\dagger$ & S.E. & MIS & PDB & PENG & INF & RGI & ZIS \\
\hline \multirow[b]{2}{*}{1} & & 100.000 & 0.00000 & 0.00000 & 0.00000 & 0.00000 & \\
\hline & 0.001706 & 0 & 0 & 0 & 0 & 0 & 0.000000 \\
\hline \multirow[b]{2}{*}{2} & & 98.4158 & 0.06835 & \begin{tabular}{|l|}
0.04639 \\
\end{tabular} & 0.00061 & & \\
\hline & 0.002967 & 1 & 4 & 3 & 1 & 1.468816 & $1.14 \mathrm{E}-05$ \\
\hline \multirow[b]{2}{*}{3} & & 96.1762 & 0.17662 & 0.07450 & 0.06348 & & \\
\hline & 0.004114 & 5 & 2 & 4 & 2 & 3.548454 & 0.012542 \\
\hline \multirow[b]{2}{*}{4} & & 93.9111 & 0.23511 & 0.08965 & 0.23813 & & \\
\hline & 0.005170 & 4 & 7 & 3 & 5 & 5.516338 & 0.068114 \\
\hline \multirow{2}{*}{5} & & 91.7541 & 0.30524 & 0.10313 & 0.50982 & & \\
\hline & 0.006150 & 2 & 8 & 2 & 2 & 7.214536 & 0.183274 \\
\hline \multirow[b]{2}{*}{6} & & 89.7039 & 0.30524 & & 0.85556 & 8.65229 & \\
\hline & 0.007066 & 8 & 8 & 0.120413 & 4 & 5 & 0.362501 \\
\hline \multirow[b]{2}{*}{7} & & 87.7287 & 0.38886 & 0.14384 & 1.259520 & 9.87544 & \\
\hline & 0.007930 & 0 & 2 & 8 & & 3 & 0.603630 \\
\hline \multirow[b]{2}{*}{8} & & 85.7962 & 0.48649 & 0.17432 & 1.71275 & 10.9289 & \\
\hline & 0.008752 & 5 & 0 & 8 & 7 & 2 & 0.901259 \\
\hline \multirow{3}{*}{9} & & 83.8822 & 0.59814 & 0.21196 & & 11.8484 & \\
\hline & 0.009541 & 7 & 3 & 4 & 2.210579 & 9 & 1.248562 \\
\hline & & 81.9705 & 0.72361 & \begin{tabular}{|l|}
0.25642 \\
\end{tabular} & 2.75042 & & \\
\hline 10 & 0.010304 & 1 & 5 & 4 & 9 & 12.66078 & 1.638237 \\
\hline
\end{tabular}

Sumber: Hasil Estimasi Menggunakan

EViews 9

\section{Pembahasan}

\section{Pengaruh PDB terhadap Kemiskinan di Indonesia}

Berdasarkan hasil estimasi VECM, dalam jangka panjang PDB berpengaruh negatif dan signifikan, sedangkan dalam jangka pendek PDB berpengaruh negatif tetapi tidak signifikan. Hasil dari penelitian ini mendukung penelitian dari Akhmad, Alyas, dan Amir (2018) dan Seto (2016) yang menyebutkan bahwa adanya pengaruh negatif PDB terhadap kemiskinan yang mana apabila PDB mengalami kenaikan maka akan mengurangi jumlah kemiskinan. Kenaikan PDB yang disebabkan oleh banyaknya hasil output berupa barang dan jasa dari perusahaan atau perorangan di dalam suatu negara yang dipengaruhi oleh naiknya permintaan dari barang dan jasa tersebut yang didasari oleh harga yang turun. Dengan banyaknya permintaan yang didasari oleh harga yang turun yang mengindikasikan adanya kenaikan daya beli dan konsumsi, memberikan indikasi adanya pengurangan kemiskinan karena orang-orang yang berada di bawah garis kemiskinan dapat memenuhi kebutuhan hidupnya.

\section{Pengaruh Pengangguran terhadap}

\section{Kemiskinan di Indonesia}

Hasil dari penelitian ini menyebutkan bahwa dalam jangka panjang pengangguran berpengaruh positif dan signifikan, sedangkan dalam jangka pendek PDB berpengaruh positif tetapi tidak signifikan. Adanya hubungan yang positif ini sesuai dengan asumsi teori 
Andrini, et al/Jurnal Ekonomi Syariah Teori dan Terapan Vol. 6 No. 7 Juli 2019: 1476-1493; PENGARUH VARIABEL MAKRO EKONOMI DAN PENYALURAN ZAKAT, INFAK, DAN SEDEKAH OLEH BADAN AMIL ZAKAT NASIONAL TERHADAP KEMISKINAN DI INDONESIA

ekonomi yang sudah ada, didukung oleh hasil penelitian Saunders (2002) dan Park dkk. (2002). Pengangguran akan mengakibatkan tidak adanya penghasilan untuk memenuhi kebutuhan hidup yang jikalau terus-menerus terjadi akan mengakibatkan kemiskinan.

Pengaruh Inflasi terhadap Kemiskinan di Indonesia

Berdasarkan hasil estimasi VECM, dalam jangka panjang inflasi berpengaruh negatif dan signifikan, sedangkan dalam jangka pendek PDB berpengaruh negatif tetapi tidak signifikan. Hasil dari penelitian ini tidak sesuai dengan teori yang ada yang menyatakan bahwa inflasi memiliki pengaruh yang positif terhadap kemiskinan. Hasil penelitian ini didukung oleh penelitian Mustamin dkk. (2015), Duwila (2016), Amalia (2012). Menurut UN Report (2010), inflasi dapat mengurangi upah tetap yang dapat menurunkan jumlah pengangguran sehingga dapat mengurangi kemiskinan. Selain itu, masyarakat miskin yang berhutang akan diuntungkan ketika membayarkan hutangnya saat inflasi karena mengurangi nilai riil hutangnya (Talukdar, 2012).

Inflasi sangat berhubungan erat dengan harga Bahan Bakar Minyak (BBM), karena apabila harga BBM naik maka akan menaikkan harga-harga barang dan jasa yang akan mengakibatkan inflasi. Namun, penetapan subsidi oleh pemerintah untuk BBM yang cukup besar yang dapat mengurangi pengeluaran masyarakat sehingga kemampuan beli masyarakat naik. Sebaliknya, apabila subsidi BBM berkurang, maka akan mengakibatkan naiknya pengeluaran masyarakat karena harga transportasi, harga kebutuhan dasar yang naik, sehingga kemampuan beli masyarakat menurun. Selain itu, jua terdapat Bantuan Langsung Tunai yang diberikan kepada masyarakat miskin sehingga dapat menurunkan angka kemiskinan (Indonesia Investments, 2018).

\section{Pengaruh Rasio Gini terhadap Kemiskinan} di Indonesia

Penelitian ini menghasilkan bahwa dalam jangka panjang rasio gini berpengaruh negatif dan signifikan, sedangkan dalam jangka pendek PDB berpengaruh negatif dan signifikan. Hasil yang didapatkan mengindikasi bahwa rasio gini yang menggambarkan ketimpangan distribusi pendapatan berpengaruh negatif terhadap kemiskinan, yang mana berbeda dengan teori yang menyatakan bahwa semakin tinggi tingkat ketimpangan maka kemiskinan menurun. Hasil yang didapatkan ini mendukung teori yang telah dikemukakan oleh Ravallion (2001) yang menyatakan bahwa ketimpangan distribusi pendapatan antar masyarakat tidak akan memengaruhi kemiskinan bahkan mengurangi jumlahnya apabila diiringi dengan rata-rata dari standar kehidupan menurun. Menurut Bappenas (2012), rasio gini yang terjadi di Indonesia tidaklah "orang yang kaya semakin kaya 
Andrini, et al/Jurnal Ekonomi Syariah Teori dan Terapan Vol. 6 No. 7 Juli 2019: 1476-1493; PENGARUH VARIABEL MAKRO EKONOMI DAN PENYALURAN ZAKAT, INFAK, DAN SEDEKAH OLEH BADAN AMIL ZAKAT NASIONAL TERHADAP KEMISKINAN DI INDONESIA

dan orang yang miskin semakin miskin", namun orang yang miskin juga meningkat kesejahteraannya. Hal ini dikarenakan bertambahnya konsumsi riil dari semua golongan masyarakat.

\section{Pengaruh ZIS dari BAZNAS terhadap Kemiskinan di Indonesia}

Berdasarkan hasil estimasi VECM, dalam jangka panjang ZIS dari BAZNAS berpengaruh negatif dan signifikan, sedangkan dalam jangka pendek PDB berpengaruh negatif tetapi tidak signifikan. ZIS memiliki fungsi sebagai pengurang dari kesenjangan ekonomi dan kemiskinan dengan menyalurkan sebagian harta orang-orang yang mampu kepada mereka yang kurang beruntung, seperti dalam QS. AdzDzariyaat ayat 19 "Dan pada harta-harta mereka ada hak untuk orang miskin yang meminta dan orang miskin yang tidak mendapat bagian".

Hasil penelitian yang diperoleh mendukung penelitian sebelumnya yang dilakukan oleh Fauziyah (2016) dan Seto (2016) yang menyatakan bahwa distribusi ZIS di BAZNAS memiliki hubungan yang negatif. Hasil yang didapatkan dari penelitian ini menunjukkan bahwa ZIS berpengaruh signifikan di dalam jangka panjang, hal ini dikarenakan tujuan dari penyaluran ZIS mengutamakan program yang produktif seperti Zakat Community Development (ZCD) dan Microfinance BAZNAS yaitu untuk membentuk kualitas sumber daya manusia yang lebih baik sehingga dapat membentuk investasi untuk jangka panjang. Pendayagunaan zakat produktif ini sejalan dengan UU No. 23 Tahun 2011 dalam pasal 27 yang menyatakan bahwa zakat produktif dapat berpengaruh untuk jangka panjang dan dapat memperbaiki kualitas umat (Mawardi dan Widiastuti, 2015: 45).

\section{SIMPULAN}

1. Variabel PDB, inflasi, rasio gini, dan distribusi ZIS dari BAZNAS memiliki pengaruh yang negatif dan signifikan terhadap kemiskinan di dalam jangka panjang. Variabel pengangguran memiliki pengaruh yang positif dan signifikan terhadap kemiskinan di dalam jangka panjang.

2. Variabel PDB, inflasi, dan distribusi ZIS dari BAZNAS berpengaruh negatif dan tidak signifikan secara statistik terhadap kemiskinan di dalam jangka pendek. Variabel rasio gini berpengaruh negatif dan signifikan secara statistik terhadap kemiskinan. Sedangkan variabel pengangguran berpengaruh positif dan tidak signifikan secara statistik terhadap kemiskinan.

3. Variabel PDB, pengangguran, inflasi, rasio gini, dan distribusi ZIS dari BAZNAS secara bersama-sama dapat memengaruhi kemiskinan di dalam jangka panjang dan jangka pendek.

\section{DAFTAR PUSTAKA}

Azis, S. A. (2009). Al-Zakah. Terj. Ummu Abdillah al-Buthoniyah. Retrieved November 24, 2018, from http://www.raudhatulmuhibbin.org 
Andrini, et al/Jurnal Ekonomi Syariah Teori dan Terapan Vol. 6 No. 7 Juli 2019: 1476-1493; PENGARUH VARIABEL MAKRO EKONOMI DAN PENYALURAN ZAKAT, INFAK, DAN SEDEKAH OLEH BADAN AMIL ZAKAT NASIONAL TERHADAP KEMISKINAN DI INDONESIA

Badan Pusat Statistik. (2017). Gini Rasio 2016 Kota Yogyakarta. Yogyakarta: Badan Pusat Statistik.

Badan Pusat Statistik. (2018). Keadaan Ketenagakerjaan Indonesia. Jakarta: Badan Pusat Statistik.

Bank Indonesia. (2016). Metadata. Jakarta: Bank Indonesia.

Bappenas. (2012). Rasio Gini di Indonesia dalam Lima Tahun Terakhir. Retrieved from Bappenas Web site: https://www.bappenas.go.id

Bappenas. (2016). Siaran Pers: Mencapai Pertumbuhan Ekonomi 5,3\% serta Pengurangan TPT $5,3-5,6 \%$ pada 2017. Jakarta: Bappenas.

Beik, I. S., \& Aprianti, W. N. (2013). Analisis Faktor-Faktor yang Memengaruhi Pembiayaan Bank Syaria untuk Sektor Pertanian di Indonesia. Jurnal Agro Ekonomi.

Hadliroh, M. (2014). Factors Influencing Poverty in East Java Province, Indonesia Year 2000-2013. Journal of Economics and Sustainable Development.

Harris, R. I. (1995). Cointegration Analysis in Econometric Modelling. Great Britain: Prentice Hall.

Indonesia Investments. (2018). Inflasi di Indonesia Harga Konsumen). Retrieved from Indonesia Investments: www.indonesia-investments.com

Jusmaliani, \& Soekarni. (2005). Kebijakan Ekonomi dalam Islam. Yogyakarta: Kreasi Wacana.
Mankiw, N. G. (2000). Teori Makro Ekonomi Edisi Keempat, ter. Imam Nurmawan. Jakarta: Penerbit Erlangga.

Mawardi, I., \& Widiastuti, T. (2015). Kesejahteraan dan Kemiskinan dalam Perspektif Islam. Surabaya: STAINA PRESS.

Putra, L. D. (2011). Analisis Pengaruh Ketimpangan Distribusi Pendapatan terhadap Jumlah Penduduk Miskin di Provinsi Jawa Tengah Periode 2000-2007. Semarang: Universitas Diponegoro. Ravallion, M. (2001). Growth, Inequality, and Povery: Looking Beyond Averages. World Development Vol. 29 No. 11.

Rosadi, D. (2011). Analisis Ekonometrika dan Runtut Waktu Terapan dengan E-Views. Yogyakarta: ANDI.

Talukdar, S. R. (2012). The Effect of Inflation on Poverty in Developing Countries: A Panel Data Analysis. Texas: Texas Tech University.

UN. (2010). Rethinking Poverty: Report on the World Social Situation. Department of Economic. 